\title{
Lithofacies Characterization and Quantitative Mineralogical Analysis of the sediments from Sahaiawei-1Well in the Northern Delta Depobelt of the Niger Delta Basin
}

\section{${ }^{1}$ LUCAS, FA; "2ITIOWE, K; ${ }^{3}$ AVWENAGHA, EO; ${ }^{3}$ ERUEBI, BT}

\author{
${ }^{1}$ Department of Geology, University of Benin, Benin City, Nigeria \\ ${ }^{2}$ Department of Earth Sciences, Arthur Jarvis University, Akpabuyo, Cross River State, Nigeria \\ ${ }^{3}$ Department of Geology, University of Port Harcourt, Choba, Port Harcourt, Nigeria \\ *Corresponding Author Email: drfalucas@gmail.com \\ Other Authors: kiamukeitiowe@yahoo.com; avwenagha.oghenero@arthurjarvisuniversity.edu.ng; bawotoju@gmail.com
}

\begin{abstract}
The sediments of Sahaiawei-1 Well in the Northern Delta Depobelt are represented by sand and shale alternation. Lithofacies characterization and X-ray diffraction technique were used to characterize the sediments from the well in order to characterize the lithofacies, identify the minerals present, determine environment of deposition and identify potential zones for hydrocarbon exploitation. The lithofacies characterization was based on the textural properties, mineralogical composition, fossil content, homogeneity and heterogeneity of the lithofacies units of the well. The lithofacies analysis for Sahaiawei-1 Well identified four (4) lithofacies types of mainly sandstone, shaly sandstone, sandy shale and shale; and fourteen (14) lithofacies zones. The result of the X-ray diffraction analysis identified the following clay minerals - kaolinite, illite/muscovite, chlorite and sepiolite; carbonates and non-clay minerals. Therefore, due to the high percentage of kaolinite in Sahaiawei-1 Well ( $2 \%$ to $39.87 \%)$, it could be concluded that pore filing kaolinite may have more effect on the reservoir quality than the pore bridging illite and pore lining chlorite.
\end{abstract}

DOI: https://dx.doi.org/10.4314/jasem.v24i10.13

Copyright: Copyright (C) 2020 Lucas et al. This is an open access article distributed under the Creative Commons Attribution License (CCL), which permits unrestricted use, distribution, and reproduction in any medium, provided the original work is properly cited.

Dates: Received: 15 August 2020; Revised: 22 September 2020; Accepted: 19 October 2020

Keywords: alternation, lithofacies, X-ray diffraction, reservoir, mineralogy.

The Niger Delta Basin is the major hydrocarbon exploration and exploitation basin in West Africa since the discovery of hydrocarbon in Oloibiri community, Bayelsa State in 1956 (Reijers et al., 1996). The growth of the delta can be traced to the origin of the Benue Trough in the early Cretaceous. The Benue Trough represents an aulacogen, which is a failed rift arm of a triple junction system linked with the opening of the South Atlantic. The growth of the Niger Delta can be seen as a function of rate of sedimentation (Rd) and rate of subsidence (RS).The delta progrades toward the gulf of Guinea. Exploration and exploitation of hydrocarbon necessitates the spatial and depth distribution of geological materials and interplay of favourable conditions (Ighodaro et al., 2016). These conditions include the distribution of source rock, reservoir rock, sealing mechanism, migration pathways and timing; these conditions are regarded to as hydrocarbon play. The hydrocarbon play element distribution in a basin is as a result of the tectonic history and basin fill. There are no much work on the lithofacies and quantitative mineralogical analysis of the sediments from the Northern Delta Depobelt. This study will provide additional information on the quality of the reservoir rock and the attributes of the hydrocarbon play elements.

*Corresponding Author Email: drfalucas@gmail.com
Geology of the Niger Delta: The evolution of Niger Delta started during the Aptian times, the region presently occupied by the Niger Delta Basin was the failed armed of the R-R-R (ridge-ridge-ridge) triple junction that led up the separation of South America from Africa plate (Burke et al., 1972). During the Eocene to Recent phase, there was initiated response to the epirogenic movement along the Benin and Calabar flanks and continued to build up the Niger Delta up till present time. This stage was marked by regression that was frequently interrupted by minor transgression (Frankl and Cordry, 1967). The variation in relation to rate of sedimentation and subsidence rate gave rise to the development of distinct sedimentary mega-units of different shapes, sizes and thicknesses. The age of these formations decrease basin-ward, reflecting the general regression of depositional environments with in the Niger Delta clastic sedimentary wedge. The Niger Delta is divided into three major stratigraphic units, which are the Akata, Agbada and Benin Formations (Reijers, 2011). The three formations occur in each of five off lapping siliciclastic sedimentation cycles that comprise the depobelts (Weber, 1987; and Weber and Daukoru, 1975). 
MATERIALS AND METHODS

Study Area: The study area is located in the Northern Delta Depobelt of the Niger Delta Basin. The well is geographically positioned on latitude $6^{\circ} 15 \mathrm{~N}$ and longitude $5^{\circ} 05 \mathrm{E}$ (Figure 1).

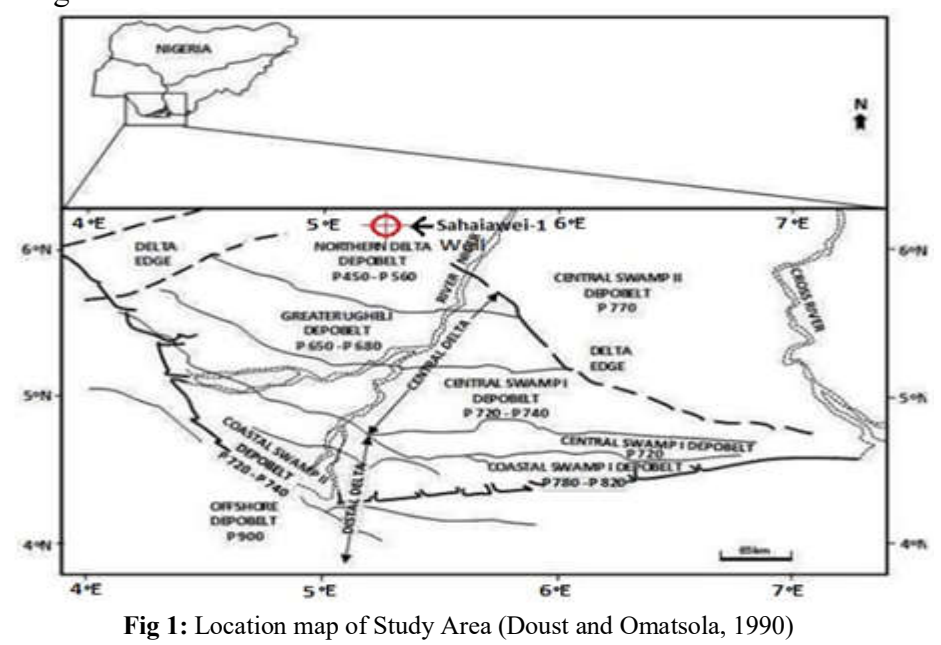

Lithofacies Characterization: A total of one hundred and fifty four (154) ditch cutting samples from Sahaiawei-1 Well between the intervals of 1600 feet to 10730 feet were taken for lithofacies analysis. Ditch cutting samples from the well were examined visually and under the reflected light microscope to determine the different lithology by considering the colour, texture (grain size, roundness, shape and sorting), mineral types and accessories such as mica, quartz, pyrite, iron oxide and carbonaceous detritus. The presence of carbonate in the sediments was tested for with $10 \%$ of diluted hydrochloric acid. Effervescence indicates carbonate presence. Lithologic log were generated from the lithofacies description of the entire ditch cutting from the well (Figure 2).

Mineralogy: Eight (8) ditch cutting samples from Sahaiawei-1 Well were selected from the shaly interval of interest for XRD preparation technique. The prepared samples were placed into the panalytical aeris diffractometer for analysis. In the course of the analysis, the phases were identified using X'Pert Highscore plus software and the relative amount (weight \%) were estimated using the Rietveld method. This study was carried out in order to characterize the lithofacies, identify the minerals present, determine the environment of deposition and identify potential zones for hydrocarbon exploitation.

\section{RESULTS AND DISCUSSION}

Lithofacies Analysis: Sahaiawei-1 well consists of fourteen lithofacies zones. Eight heterogenetic zones and six homogenetic zones (Figure 2).
Lithofacies Zone 1-(1600-1740ft): This is a sandstone unit with bed thickness of about $240 \mathrm{ft}$. The sand grain is whitish, fine to pebbles grain, angular to rounded, poorly to moderately sorted, $0-10 \%$ coal is present in this unit. Iron oxide is the mineral present in this unit.

Lithofacies Zone 2 - (1740-1980ft): This is a shaly sandstone unit with bed thickness of about $240 \mathrm{ft}$. The sand grain is whitish, fine to granules, angular to subrounded, poorly sorted, clay, $0-10 \%$ coal is present. Iron oxide is the mineral present in this unit.

Lithofacies Zone 3-(1980-2100ft): This is a sandstone unit with bed thickness of about $120 \mathrm{ft}$. The sand grain is whitish, fine to medium grain, sub-rounded to rounded, moderately sorted, $0-15 \%$ coal is present.

Lithofacies Zone 4- (2100-2160ft): This is a shaly sandstone unit with bed thickness of about $60 \mathrm{ft}$. The sandstone is whitish, fine to medium grain, angular to sub-rounded, moderately sorted, coal is present. The mineral present in this unit is iron oxide.

Lithofacies Zone 5-(2160-2400ft): This is a sandstone unit with bed thickness of about $240 \mathrm{ft}$. The sand grain is whitish, fine to medium grain, angular-rounded, moderately to well sorted, and coal is present.

Lithofacies Zone 6 - (2400-2520ft): This is a shaly sandstone unit with bed thickness of about $120 \mathrm{ft}$. The sand grain is whitish, fine to coarse grain, angular to sub-rounded, moderately sorted, coal is present.

Lithofacies Zone 7-(2700-4320ft): This is a sandstone unit with bed thickness of about $1620 \mathrm{ft}$. The sand grain 
is whitish, fine to coarse grain, angular to rounded, moderately sorted, clay, coal is present.

Lithofacies Zone 8 - (4320-4440ft): This is a shaly sandstone unit with bed thickness of about $120 \mathrm{ft}$. The sand is whitish, fine to granules grain, angular to subrounded, poorly to well sorted, plant rootlets, clay, coal is present. The mineral present in this unit are iron oxide, pyrite and mica.

Lithofacies Zone 9 - (4440-4500ft): This is a sandy shale unit with bed thickness of about $120 \mathrm{ft}$. The shale is fine grained and fissile, 55-60\% shale, coal is present. Iron oxide is the mineral present in this unit.

Lithofacies Zone 10 - (4500-4560ft): This is a shaly sandstone unit with bed thickness of about $60 \mathrm{ft}$. The sand is whitish, fine to medium grain, sub-angular to rounded, well sorted, coal is present. Iron oxide is the mineral present in this unit.
Lithofacies Zone 11- (4500-5280ft): This is a sandy shale unit with bed thickness of about $780 \mathrm{ft}$. The shale is grayish, fine grained and fissile, $55-90 \%$ shale, coal is present in this unit. Iron oxide and mica are the minerals present in this unit.

Lithofacies Zone $12-(5280-5400 f t)$ : This is a shale unit with a bed thickness of about $120 \mathrm{ft}$. The shale is grayish, fine grained and fissile indicating oxygen deficient environment.

Lithofacies Zone 13 - (5400-5700ft): This is a sandy shale unit with bed thickness of about $300 \mathrm{ft}$. The shale is grayish, Fine grain and fissile, $98 \%$ shale, coal is present.

Lithofacies Zone 14 - (5700-10830ft): This is a shale unit with a bed thickness of about $5130 \mathrm{ft}$. The shale is dark grey, fine grained and fissile which indicates a quiet and an anoxic condition. Iron oxide is the mineral present in this unit.

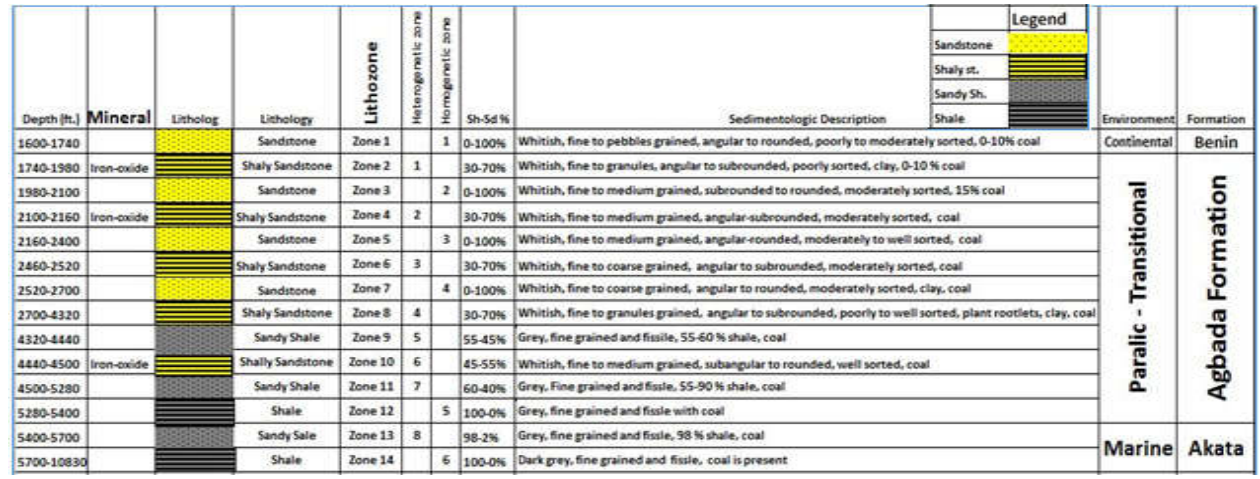

Fig 2: Lithostratigraphic model for Sahaiawei-1 Well

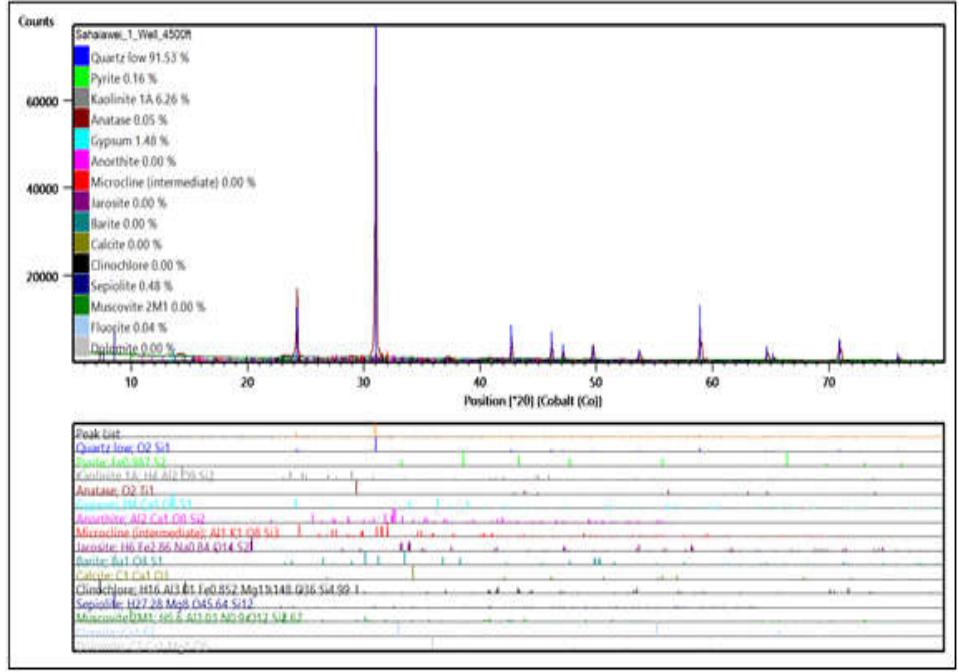

Fig 3: XRD Diffractogram for Sahaiawei-1 Well at 4500ft.
Mineralogy: The shale from the Northern Delta Depobelts constitute significance source rock and seal for the hydrocarbon trapped in the sandstone reservoir rock of the well. The prediction of the reservoir characteristics has become a major challenge for hydrocarbon exploration and development. An understanding of the shale which constitutes the clay is important in understanding the characteristics of the reservoir and the oil recovery efficiency. The whole-rock mineral assemblages of the shale of Sahaiawei-1 Well are predominantly of quartz and clay minerals. The minerals present in Sahaiawei-1 Well are shown in the 
XRD Diffractogram (Figure 3, 4, 5 and 6).

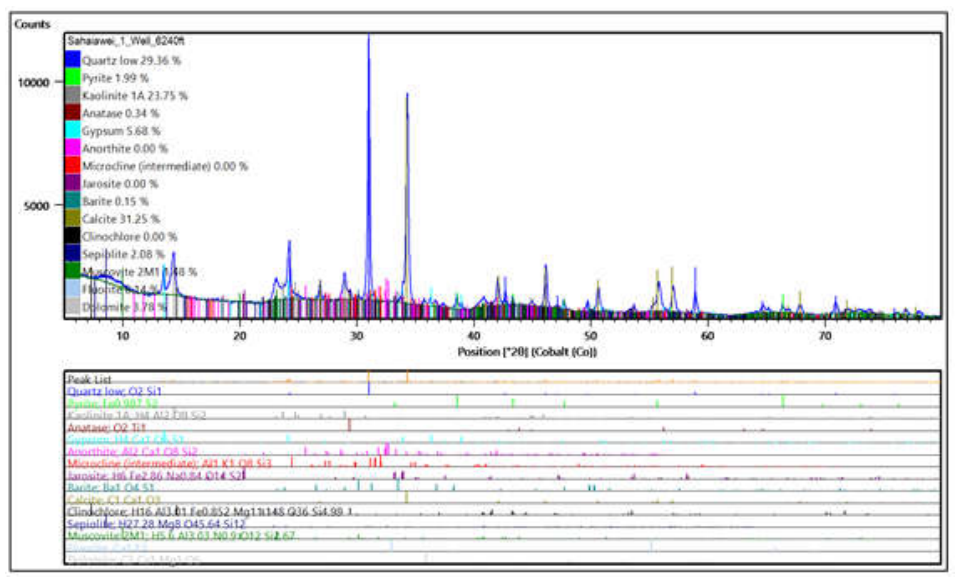

Fig 4: XRD Diffractogram for Sahaiawei-1 Well at $6240 \mathrm{ft}$.

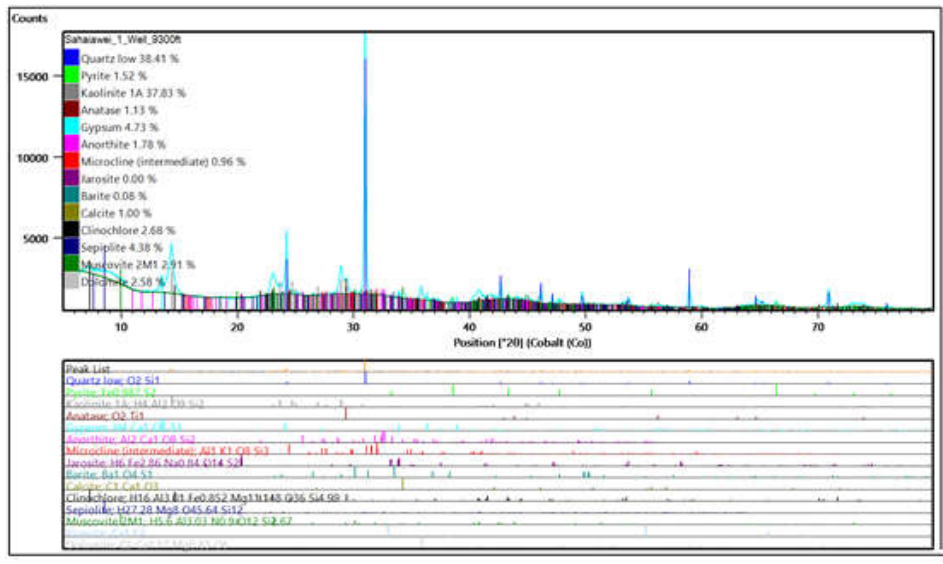

Fig 5: XRD Diffractogram for Sahaiawei-1 Well at $9300 \mathrm{ft}$.

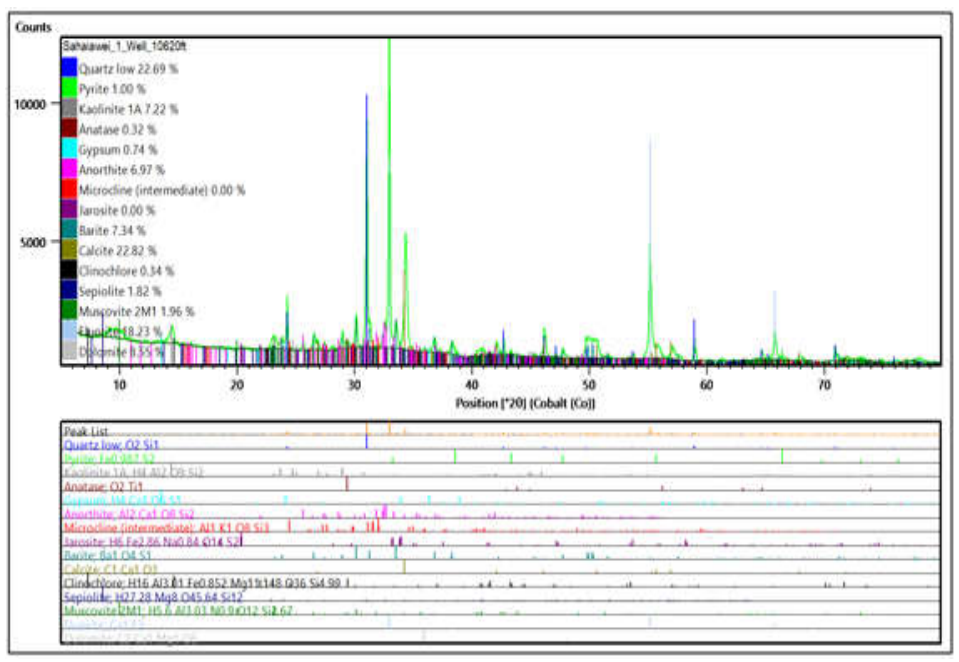

Fig 6: XRD Diffractogram for Sahaiawei-1 Well at $10620 \mathrm{ft}$.
Quantitative Analysis of Minerals Clay Minerals: The total clay mineral content of the whole-rock mineral assemblage varies between $2.22 \%$ to $44.96 \%$ (Table 1 ). The total clay mineral could be as low as $2.22 \%$ reflecting high silt component or abundance of carbonate cement.

Kaolinite: Kaolinite is the most abundant clay mineral species in the well, with amount ranging from $2 \%$ to $39.87 \%$ (mean, $21.43 \%$ ). The relative amount of kaolinite appears to increase gradually with depth in Sahaiawei-1 Well.

Illite/muscovite: Illite/muscovite occurs as a relatively minor clay mineral component in all the samples investigated with abundance varying between 0 to $3.94 \%$ (mean, $1.72 \%$ ). The variation observed in the illite/muscovite abundance in the well may reflect difference in depositional environments.

Chlorite: The occurrence of chlorite studied is relatively minute. The percentage of chlorite varies from $0 \%$ to $2.68 \%$ (mean, $0.815 \%$ ). The chlorite percentage increases with depth.

Sepiolite: The percentage of sepiolite tends to increase with depth. The percentage varies from $0 \%$ to $10.1 \%$ (mean, $3.32 \%$ ).

Non-Clay Minerals: The non-clay minerals in the shale include quartz, microcline, plagioclase, pyrite, anatase, jarosite, barite, fluorite, carbonate and dolomite.

Quartz: Quartz is the predominant non-clay mineral in the shale. It varies abundance varies from $22.69 \%$ to $96 \%$ (mean, $48.1 \%$ ). The low percentage of quartz with depth could be as a result increasing amount of clay minerals. 
Feldspar (Microcline and Plagioclase): The percentage of feldspar in the rock is generally low. The percentage of microcline is generally less than that of plagioclase feldspar. Microcline generally increases with depth; the percentage varies from $0 \%$ to $5.04 \%$ (mean, $0.94 \%$ ). The plagioclase varies from $0 \%$ to $2.77 \%$ (mean, $1.46 \%$ ). Other non-clay minerals for in the well include siderite, dolomite, calcite, pyrite, anatase, jarosite, barite and fluorite.

Table 1: Bulk XRD Analysis for Sahaiawei-1 Well

\begin{tabular}{llllllllllllllllll}
\hline Depth (ft) Kao. & Illite & Chl. & Sep. Cal. & Dol. Qtz. & Pyr. & Ana. Gyp. Plag. Micr. Jaro. Ba. & Flu. \\
\hline 3060 & 2 & 0.19 & 0.03 & 0 & 0 & 0 & 96 & 0 & 0 & 0.92 & 0 & 0 & 0.86 & 0 & 0 \\
4500 & 6.26 & 0 & 0 & 0.48 & 0 & 0 & 91.53 & 0.16 & 0.05 & 1.48 & 0 & 0 & 0 & 0 & 0.04 \\
5160 & 39.87 & 1 & 0.28 & 2.87 & 0.18 & 0 & 41.38 & 0.56 & 0.55 & 4.9 & 2.77 & 5.04 & 0.61 & 0 & 0 \\
6240 & 23.75 & 1.48 & 0 & 2.08 & 31.25 & 3.78 & 29.36 & 1.99 & 0.34 & 5.68 & 0 & 0 & 0 & 0.15 & 0.14 \\
7440 & 25.34 & 2.3 & 1.68 & 4.79 & 2.72 & 14.18 & 41.13 & 1.54 & 0.61 & 3.55 & 0 & 1.48 & 0 & 0.67 & 0 \\
8700 & 29.21 & 3.94 & 1.71 & 10.1 & 4.15 & 2.39 & 23.97 & 0.77 & 0.79 & 0.28 & 0.13 & 0 & 0 & 22.57 & 0 \\
9300 & 37.83 & 2.91 & 2.68 & 4.38 & 1 & 2.58 & 38.41 & 1.52 & 1.13 & 4.73 & 1.78 & 0.96 & 0 & 0.08 & 0 \\
10620 & 7.22 & 1.96 & 0.34 & 1.82 & 22.82 & 8.55 & 22.69 & 1 & 0.32 & 0.74 & 6.97 & 0 & 0 & 7.34 & 18.23 \\
\hline
\end{tabular}

Prediction of reservoir quality: The prediction of reservoir characteristics has become a key challenge for exploration and development of hydrocarbon in oil fields. This study shows the presence of kaolinite, illite/muscovite, chlorite and sepiolite. Clay minerals have important roles on improved oil recovery efficiency, as these minerals have different effects in controlling the reservoir characteristics, wettability and mobility of oil. Both authigenic and allogenic clays have different roles in modifying the reservoir properties and as a result have different roles on the oil recovery efficiency. Kaolinite could also be counted as an important constituent in determining the reservoir quality (Minati and Nayan, 2015). Kaolinite adsorbs oil in the reservoir rock which makes the rock oil wet (Tang and Morrow, 1999). Since this oil wet rock has the characteristic to imbibe oil, as we go down the depth, the wettability of the rock increases. Tang and Morrow (1999) discovered that the migration of kaolinite in the sandstone reservoir during low saline water flooding (LSW) increases the water wetness of the reservoir rock by exposing new underlying rock surface which successfully improve the oil recovery efficiency. They found a reduction in permeability of the reservoir rock which may be due to blocking some of the available pore space of the reservoir rock by the migrated kaolinite. Therefore, if low saline water flooding (LSW) has been carried out in Sahaiawei-1 Well, there is possibility that there could be a reduction in the permeability in the reservoir as a result of the pore filing kaolinite.

The success of any enhanced oil recovery method may be controlled by the type and amount of clay mineral in the reservoir and the method that is been applied. Since illite has flaky habit, there is possibility that it could bridge the pores which could reduce the porosity and permeability. Mohan et al., (1993), observed that illite which is non-swelling clay tend to come off from the rock surface and move with the injection water when the salt concentration of the injection water is low. The migrating particle (illite) may get trapped in the pore throat causing a reduction of reservoir permeability. It can be seen that loss of permeability of a reservoir can be attributed to the migration of clay mineral. Since illite occurs as a minor clay mineral component in the well, the possibility that there will be loss of reservoir permeability if enhanced oil recovery has been carried out in the well will be minimal. The percentage of chlorite in Sahaiawei-1 Well increases with depth. The low percentage of chlorite in the well shows that the pore lining characteristics of chlorite may not affect the reservoir quality.

Implication for hydrocarbon exploration: Lithofacies characterization has been demonstrated to be a hierarchical stratigraphic technique that can be applied in characterizing potential source and reservoir rock in any well (Ighodaro et al. 2016). The migrating particle (illite) may get trapped in the pore throat causing a reduction of reservoir permeability. It can be seen that loss of the permeability of a reservoir can be attributed to the migration of clay mineral. Since illite occur as minor clay mineral component in the well, the possibility that there will be loss of reservoir permeability if enhanced oil recovery has been carried out in well will be minimal.

Reijers (2011) and Short and Stauble (1967) cited that the source and reservoir rocks are within the Agbada Formation. In Sahaiawei-1 Well, the potential source rock zones are within the homogenetic zone 1 to zone 4 (5300ft. to $10830 \mathrm{ft}$.) because these zones contain mainly shale lithology, while the reservoir rock is within heterogenetic zone 6 (4440ft. to $4500 \mathrm{ft}$.) because this zone is predominantly sand; the sand could serve as reservoir (Figure 2).

Environment of Deposition: The textural properties, mineralogical composition, fossil content, shale to 
sand ratio, homogeneity and heterogeneity of the lithofacies units for the well provided clue to the environment of deposition (Figure 2). Sedimentary characteristics used to identify depositional environment for Sahaiawei-1 Well are similar to those defined by Boggs (2006). Boggs (2006) used the percentages of shale to sand intercalation to determine the environment of deposition. Considering the percentages of shale to sand (0 to $100 \%)$ at depth $1600 \mathrm{ft}$. to $1740 \mathrm{ft}$. the environment of deposition for these zones is considered to be continental. The percentages of shale to sand at depth $1740 \mathrm{ft}$. to $5280 \mathrm{ft}$. is from $30 \%$ to $70 \%$, the environment of deposition for these zones is considered to be paralic to transitional. From depth $5400 \mathrm{ft}$. to depth $10830 \mathrm{ft}$. is predominantly shale, therefore marine environment is considered for these zones.

Conclusion: The lithofacies characterization and quantitative mineralogical analysis have been carried out on the sediments from Sahaiawei-1Well. Considering the textural properties, mineralogical composition, fossil content, lithofacies units, shale to sand ratio, the clay and non-clay minerals, it can be concluded that the well has potential zones for hydrocarbon exploitation. This research work has provided up to date information on the lithofacies and the quantitative mineralogical analysis of sediments in the Northern Delta Depobelt.

Acknowledgements: The authors are thankful to the Department of Geology, University of Benin for access to their laboratory facility and also to the management of XRD analytical and Consulting Company, South Africa, for the XRD Analysis.

\section{REFERENCES}

Boggs, S (2006). Principles of Sedimentology and Stratigraphy (fourth edition).Pearson, Prenntice Hall, Upper Saddle River, New Jersey.

Doust, HE; Omatsola, E (1990). Niger Delta. In: Edwards J. D. and Santagrossi, P. A (eds), Divergent/Passive Basins. AAPG. Bull. Mem. 45: 201-238.

Frankl, EJ; Cordry, EA (1967). The Niger Delta recent Developments Onshore and Offshore. 7th World Petroleum Congress, Mexico City, Proceedings. 2: 125-209.
Ighodaro, E J; Lucas FA; Imasuen OI; Omodolor HE (2016). Sedimentological Resolution of Hydrocarbon Play Elements of OGE-\#1 Well, Greater Ughelli Depo-Belt, Niger Delta Basin. Inter. J. Sci. Tech. Res. 5 (06) 173-183.

Minati, D; Nayan, M (2015). Clay Minerals and its Importance on Hydrocarbon Production Potential in a part of Geleki oilfield of Upper Assam Basin. Inter. J. Res. Eng. Appl. Sci. 5 (11) 25-33.

Mohan, KK; Vaidya, RN; Reed, MG; Fogler HS (1993). Water sensitivity of sandstones containing swelling and non-swelling clays, Colloids and Surfaces A: Physicochemical and Engineering Aspects. 73:237-254.

Reijers, TJA; Petters, SW; Nwajide, CS (1996). The Niger Delta Basin, in: T.J.A. Reijers (ed.), Selected Chapters on Geology: SPDC corporate reprographic services, Warri, Nigeria, pp. 103114.

Reijers, TJA (2011). Stratigraphy and Sedimentology of the Niger Delta. Geologos. 17(3) 133-822.

Short, KC; Stauble, AJ (1967). Outline Geology of Niger Delta: AAPG Bulletin. 51:761-779.

Tang, GQ; Morrow, NR (1999). Influence of Brine Composition and Fines Migration on Crude Oil/Brine/Rock Interactions and Oil Recovery. $J$. Petrol. Sci. Eng. 24: 99-111.

Weber, KJ (1987). Hydrocarbon distribution patterns in Nigeria growth faults structures controlled by structural style and stratigraphy: J. Petrol. Sci. Eng. 1: 91-104.

Weber, KJ; Daukoru, EM (1975). Petroleum geology of the Niger Delta. In Proceedings of the 9th World Petroleum Congress, Geology. : Applied Science Publishers, Ltd. London. 2: 210-221. 